Saudi Journal of Business and Management Studies Abbreviated Key Title: Saudi J Bus Manag Stud ISSN 2415-6663 (Print) |ISSN 2415-6671 (Online) Scholars Middle East Publishers, Dubai, United Arab Emirates Journal homepage: https://saudijournals.com/sibms

Original Research Article

\title{
Exploring the Embedment of Research into Mainstream Curriculum for Undergraduate Management Studies
}

\author{
Dr. Asha Alexander \\ Department of Business Administration, Jubail University College, Female Branch, P.O Box 10074,Jubail Industrial City 31961, Kingdom Of Saudi \\ Arabia
}

\begin{abstract}
DOI: $10.36348 /$ sjbms.2020.v05i02.002 | Received: 30.01 .2020 | Accepted: 06.02.2020 | Published: 12.02 .2020
*Corresponding author: Dr. Asha Alexander

\section{Abstract}

The aim of this study is to explore research skills and abilities that can be embedded into the mainstream curriculum for undergraduate management studies. The paper draws on surveys and relevant literature in the field of undergraduate research and explores the extent to which research skills and abilities can be incorporated in curriculum development at undergraduate level. It further proposes strategies in teaching and assessment for research framework that can be embedded into the main stream curriculum for undergraduate management studies.

Keyword: Higher education, undergraduate research, management studies, inquiry based learning.

Copyright @ 2020: This is an open-access article distributed under the terms of the Creative Commons Attribution license which permits unrestricted use, distribution, and reproduction in any medium for non-commercial use (NonCommercial, or CC-BY-NC) provided the original author and source are credited.

\section{INTRODUCTION}

The need for undergraduate research in management studies

Higher education is stirring from acquisition of knowledge and skills to professional capabilities. Research plays a vital part in the students' contribution for preferred career. Research activities enhances all required managerial competences in an integrated ways in Academia [1]. The pursuit of research proceeds to rethink and explore fundamental concepts for undergraduate management education. Scholars around the world have validated that undergraduate research considerably improves student learning $[2,3]$.

Although research is given in the work life, research is likewise made use in teaching through teacher inputs gained through the experience of pursuing research.Undergraduate research may represent diverse practices and be named in a different way through out international contexts [2]. The deepest engagement occurs when students start working in close relationship in all phases of the research process along with their academic staff [4]. Mentors' roles have been exhibited by faculty members in supporting student learning in course embedded in undergraduate [2] and undergraduate theses [5]. Research work at undergraduate level enriches mentoring, teaching and a sensation of achievement of scholarly and creative outcomes among the academic scholars.

The Research curriculum: Theoretical back ground Research is a journey of threefold transformation from the level of 'Trading' to 'Domino' to 'Layer ' [6]. Healey's [1] systematized the research variants as termed by Griffiths [7] into 'research-led', 'research-oriented', 'research-based' and "researchtutored'. Researchers captured ways by which research and teaching can be associated by categorizing the research content into four approaches namely researchled, research-tutored, research-oriented and researchbased [8]. An altered distinction was proposed by Levy and Petrulis [9] on basis of the inquiry and the student's relationship with knowledge. Scholars tend to agree that more open and more active forms of student-led inquiry strengthen the research-teaching connection in university education and contributes on the part of students as either learning current insights, or as 'participants in research' [10]. 
Asha Alexander; Saudi J Bus Manag Stud, Feb., 2020; 5(2): 112-117

The Adelaide Research Skills Development Framework focused on a holistic, yet consistent and explicit method for cultivating research skills to help build the prerequisite skill for success in undergraduate research [11]. There are numerous case studies on wide range of initiatives embedding the undergraduate research into the mainstream curriculum from Australasia, Europe and North America. These demonstrate some of the approaches that have been adopted and disseminated for developing researchbased curricula and engaging students in in undergraduate research. The undergraduate research movement in the United States has delivered a dominant and influential stimulus to ensure that selected students in selected institutions can learn through inquiry and research. An investigation was undertaken for selected and broadly represented US undergraduate research programs for mainstream student inquiry and research. The main objective was to widely disseminate the result in all higher education institutions in a sustainable way in the United Kingdom. In the UK the national system has progressively embarked on increasing best practices in strengthening subject centered teaching-research associations [12].

Business education in Saudi Arabia needs to educate future leaders with a new set of skills based on practical wisdom, global thinking, entrepreneurial and innovative talents and decision-making. Poor critical thinking is the chief cause of inadequate decision making in Businesses [13]. Some students will go out to be researchers in their own ways, but the prerequisites for graduates will be to build up research potential as well as holistic development of competencies for a sustainable environment. Regardless of the advantages of close student-staff collaboration throughout the research process, university practices often distance students of full participation in university research [14]. The inclination to learning is in the Middle East and particularly among Saudi students is heavily influenced by historical and cultural position. This is deep-rooted in regurgitation of memorized facts. There exists contentment with doing the minimum just to get by, resulting in inadequate study habits $[15,16]$. The increasing affluence seems to affect student commitment and motivation to memorize in a rich manner [17].

The primary focal point of this research report is to increase student engagement through researchguided learning and supply budding research scholars with research skills, abilities and deep critical enquiry thereby generating knowledge worker. The session will further explore the diversity of ways in which undergraduate research and research based learning can stimulate learning development from beginning to final year using various instruction and assessment schemes. The study will append to the sparse literature on the embedment of research into mainstream curriculum for undergraduate management studies. The Prime research question of this work was, "How can you bring about embedment of research into mainstream curriculum for undergraduate management studies?"

\section{RESEARCH METHOD}

The research work focuses on 'mixed-methods research', which makes utilization of both qualitative and quantitative data and provides advantages through triangulation. The universe of study includes data from the graduates involved in research projects during their graduation projects and faculty members of management fraternity who have guided research projects in the eastern region of Kingdom of Saudi Arabia. The research objectives are (a) graduates perception about the extent to which research skills and abilities can be enhanced in curriculum framework development at undergraduate level (b) Faculty proposition about strategies in teaching and assessment for research curriculum framework that can be embedded into the main stream curriculum.

Structured questionnaire comprising of 11 statements. Each statement represent variables representing various research skills and abilities. Variables covered in the questionnaire included inspirational capability, Problem Solving, Literature Reading skills, Critical thinking, Quantitative skills, Research Writing skills, Computing Skills, Innovative thinking, Resourceful, Team Building and Respecting Ethical code. All the questions have five point Likert scale with five ranges, starting from strongly disagree (1) to strongly agree (5). The surveys were circulated among the graduates of management fraternity .The statistical tools are Reliability test, correlation analysis and multiple regressions using SPSS (Statistical Package for Social Science).

The Narrations of Faculty focus group related to level of research, Focus in term of pedagogy and teaching strategies, contact hours and assessment strategies were collected, complied and summarized.

\section{RESULTS AND DISCUSSIONS}

\section{A) Graduates perception about the extent to which research skills and abilities can be enhanced by changes in curriculum framework at undergraduate level}

The below statistical test were conducted and analyzed to examine the significance of different identified variables and the extent of their relationship with research performance.

\section{Reliability Test}

The Cronbach's alpha coefficient was run to ascertain the reliability of all the questionnaire items. The value of alpha coefficient for all items is above $0.75-0.81$ as shown in Table-1 Reliability Analysis. According to George and Mallery [21] the reliability of each group of items is as $>0.90=$ Excellent, $0.80-0.89$ $=$ Good, $0.70-0.79=$ Acceptable, $0.60-0.69=$ 
Questionable, $0.50-0.59=$ Poor and $<0.50=$ Unacceptable. The nearer the Cronbach's alpha coefficient is to 1 the greater the internal consistency of items in the scale. The values shows in Table-1 that the items have a better internal consistency. Hence, it can be established that the questionnaire is reliable.

\section{Descriptive Analysis}

Table-2 displays the descriptive statistics of the 11 variables of Research Performance. Descriptive Analysis refers to basic features of the data in a significant way. The mean of the variables are above the mid-point on a five point Likert scale. The mean is maximum for 'respecting ethical code' it can be concluded that all the other variables are also of great significance for research performance.

\section{Correlation}

A Pearson product correlation was calculated to ascertain the relationship between research performance and respective variables. If the result number is more nearer to the number 1 it means the relationship between two variables is much stronger. The plus sign with result number indicates a positive correlation while a minus sign indicates a negative correlation. Table-3. Displays Pearson's $r$ with a plus sign between all of the respective determinants and research performance. Therefore, there is a positive relationship between the 11 determinants and the research performance. The $\mathrm{p}$-value point to a significant correlation at 0.01 level inferring that there is a significant and positive correlation between the 11 determinants and research performance.

\section{Multiple Regression}

Multiple Regression test helped in projecting the relationship between 11 independent variables and the dependent variable which is research performance. In Table-4 the variance for Problem Solving is 32, Literature Reading skills is 94, Critical thinking is 43, Quantitative skills is 95, Research Writing skills is 121,Computing Skills is 125, Innovative thinking is 72 , Resourceful is 17 ,Team Building 81 is and Respecting Ethical code 74. The value of 'p' is 0.000 for all the variables which indicate that all the amount of association among the variables are highly significant and the model is highly valid. (b) Faculty proposition about strategies in teaching and assessment for research framework that can be embedded into the main stream curriculum

One to one interviews were conducted to deliver proposition from the faculty members of the management fraternity regarding strategies in teaching and assessment framework for research. All the narratives were summarized to build a research framework for embedment into the mainstream curriculum. The students learning style and Blooms taxonomy were taken into consideration for building research framework.

Learners fall under styles of diverges, assimilators, converges or accommodations with a connected range of traits [18, 19]. The features of inquiry-based learning are recognizable in every learning style and the most ease with experiential learning are the accommodators. Bloom's taxonomy demonstrates the students move along a continuum and create up the vertical axis while the horizontal axis identifies the degree of student autonomy and can be seen as going from a low level of autonomy (students working along a closed inquiry, requiring structure and guidance) to a high level of autonomy (students working along an open inquiry). The different points of inquiry, start from confirmation inquiry to structured inquiry to guided inquiry to come to 'true' or 'open' inquiry was brought into thoughtfulness. It can be considered that the fourth layer of inquiry describes the graduate thesis process, although advocates of inquirybased learning have advocated its value at all stages of instruction.

The proposed undergraduate research framework will occur within the parameters set by the program as shown in Table-5. It will be embedded in the mainstream curriculum as a course in freshman, sophomore .junior and senior levels. It will have clear course description, curriculum framework, structure of assessments and resource required the learning outcomes will help to communicate expectations to the students .Significant care will be delivered for the growth of critical thinking, integrative problem-solving and teamwork [20]. The above characteristics facilitate learning and can enhance academic achievement and higher order learning outcomes to promote reflection. This pedagogy will enable students for self-directed learning and become life-long learners progressively by preparing them for case studies report, poster presentation, paper presentation and publication of research paper. 


\section{Appendix}

\begin{tabular}{|c|c|c|c|c|c|c|c|c|c|c|c|}
\hline & 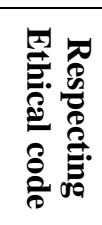 & 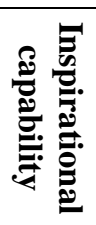 & 莺 & 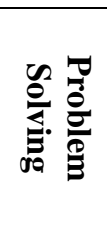 & 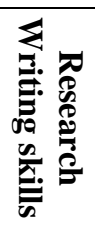 & 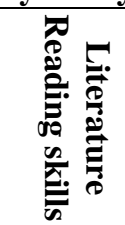 & 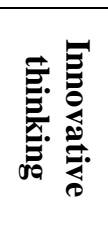 & 局: & 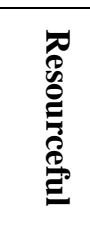 & 的 & 离 \\
\hline $\begin{array}{l}\text { Cronbach's } \\
\text { Alpha }\end{array}$ & 0.81 & 0.82 & 077 & 0.76 & 0.79 & 0.78 & 0.80 & 0.75 & 0.79 & 0.75 & 0.77 \\
\hline
\end{tabular}

Table-2: Descriptive Analysis

\begin{tabular}{|c|c|c|c|c|c|c|c|c|c|c|c|}
\hline & 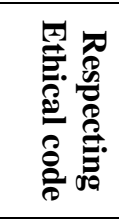 & 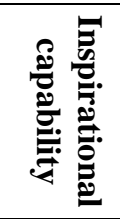 & 焉 & 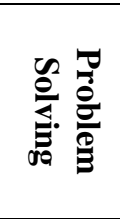 & 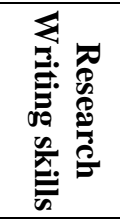 & 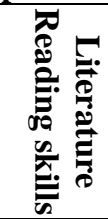 & 司: & 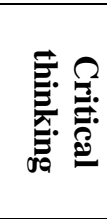 & 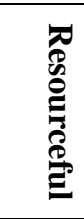 & 次 & 象 \\
\hline Mean & 4.05 & 3.76 & 4.03 & 3.78 & 3.86 & 3.78 & 3.81 & 3.89 & 3.86 & 3.71 & 3.84 \\
\hline
\end{tabular}

Table-3: Correlation Analysis

\begin{tabular}{|c|c|c|c|c|c|c|c|c|c|c|c|}
\hline & 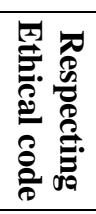 & 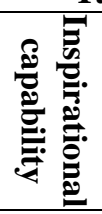 & 猬 & 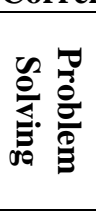 & 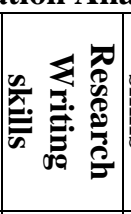 & 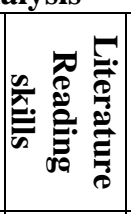 & 를. & 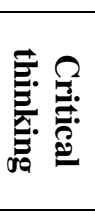 & 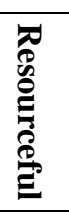 & 依 & 娧 \\
\hline Respecting Ethical code & 1 & & & & & & & & & & \\
\hline Inspirational capability & .31 & 1 & & & & & & & & & \\
\hline Team Building & .54 & .29 & 1 & & & & & & & & \\
\hline Problem Solving & .32 & .47 & .23 & 1 & & & & & & & \\
\hline Research Writing skills & .35 & .30 & .39 & .23 & 1 & & & & & & \\
\hline Literature Reading skills & .31 & .51 & .48 & .48 & .29 & 1 & & & & & \\
\hline Innovative thinking & .47 & .33 & .36 & .36 & .48 & .37 & 1 & & & & \\
\hline Critical thinking & .33 & .23 & .39 & .39 & .28 & .38 & .46 & 1 & & & \\
\hline Resourceful & .49 & .26 & .28 & .28 & .28 & .29 & .47 & .41 & 1 & & \\
\hline Quantitative skills & .37 & .36 & .33 & .33 & .28 & .25 & .43 & .42 & .52 & 1 & \\
\hline Computing Skills & .41 & .36 & .31 & .45 & .22 & .40 & .33 &. .31 & .57 & .49 & 1 \\
\hline
\end{tabular}

Table-4: Multiple Regression Analysis

\begin{tabular}{|c|c|c|c|c|c|c|c|c|c|c|c|}
\hline & 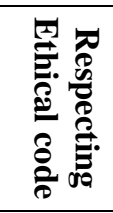 & 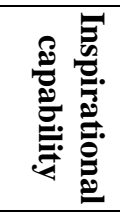 & 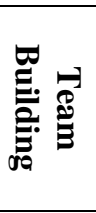 & 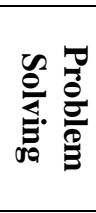 & 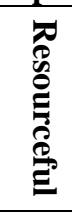 & 的离 & 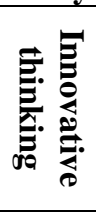 & 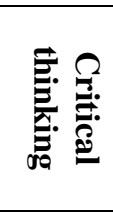 & 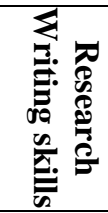 & 䋨 & 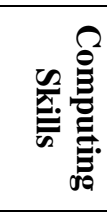 \\
\hline $\mathbf{R}^{2}$ & .44 & .45 & .46 & .25 & .15 & .50 & .43 & .31 & .56 & .45 & .57 \\
\hline${ }^{\text {Adjusted }} \mathbf{R}^{2}$ & .43 & .44 & .46 & .25 & .14 & .49 & .44 & .30 & .56 & .49 & .56 \\
\hline $\mathbf{F}$ & 74 & 77 & 81 & 32 & 17 & 94 & 72 & 43 & 121 & 95 & 125 \\
\hline
\end{tabular}


Table-5: Research curriculumFramework

\begin{tabular}{|c|c|c|c|c|}
\hline & $\begin{array}{l}\text { Research } \\
\text { Methodology For } \\
\text { Freshman }\end{array}$ & $\begin{array}{l}\text { Research Methodology } \\
\text { For Sophomore }\end{array}$ & $\begin{array}{l}\text { Research Methodology For } \\
\text { Junior }\end{array}$ & $\begin{array}{l}\text { Research Methodology } \\
\text { For Senior }\end{array}$ \\
\hline $\begin{array}{l}\text { Level of } \\
\text { research }\end{array}$ & $\begin{array}{l}\text { Research is } \\
\text { conducted at the } \\
\text { level of a closed } \\
\text { inquiry and they are } \\
\text { provided with } \\
\text { structured } \\
\text { guidelines within } \\
\text { the program }\end{array}$ & $\begin{array}{l}\text { Research happens at the } \\
\text { level of a } \\
\text { closed inquiry, but } \\
\text { independently and } \\
\text { autonomous in } \\
\text { accordance within the } \\
\text { program. }\end{array}$ & $\begin{array}{l}\text { The level of research shifts to } \\
\text { open inquiry, but within the } \\
\text { framework of } \\
\text { structured guidelines within } \\
\text { the program. }\end{array}$ & $\begin{array}{l}\text { The level of Research is } \\
\text { open inquiry with } \\
\text { self-determined guiding } \\
\text { principle within the } \\
\text { program }\end{array}$ \\
\hline $\begin{array}{l}\text { Teaching } \\
\text { Focus }\end{array}$ & $\begin{array}{l}\text { The focus is on case } \\
\text { studies that denote } \\
\text { practices within } \\
\text { organizations. } \\
\text { Discuss the Review } \\
\text { of Literature } \\
\text { Provide an } \\
\text { overview of Case } \\
\text { Reports as a } \\
\text { "research" vehicle } \\
\text { and present the case } \\
\text { report in structured } \\
\text { format }\end{array}$ & $\begin{array}{l}\text { The focus is on } \\
\text { conceptual paper. The } \\
\text { analysis and review of } \\
\text { these papers will help to } \\
\text { frame hypotheses, Final } \\
\text { presentation of the work } \\
\text { is by carrying out Poster } \\
\text { presentation } \\
\text { summarizing main } \\
\text { objectives, brief } \\
\text { modules on each } \\
\text { sections and finding. } \\
\text { Exposure to One-on-one } \\
\text { discussion as well as } \\
\text { respond to questions } \\
\text { from each viewer }\end{array}$ & $\begin{array}{l}\text { The focus is on paper } \\
\text { presentation on a relevant } \\
\text { topic related to emerging } \\
\text { trends in the discipline through } \\
\text { evaluation of literature, } \\
\text { specifying hypotheses, } \\
\text { objectives and finding Final } \\
\text { presentation of work is using } \\
\text { power point slides with } \\
\text { bulleted phrases charts and } \\
\text { tables. Exposure to panel } \\
\text { discussion and questions from } \\
\text { the audience. }\end{array}$ & $\begin{array}{l}\text { The focus is on writing } \\
\text { Research paper which } \\
\text { report research } \\
\text { methodology the research } \\
\text { activities, designing and } \\
\text { implementing } \\
\text { questionnaires, interviews, } \\
\text { Quantitative and qualitative } \\
\text { data gathering implications } \\
\text { of the research, including } \\
\text { the limitations of the } \\
\text { results. Present the work in } \\
\text { the form of full sentences } \\
\text { and paragraph in formal } \\
\text { essay structure in house } \\
\text { journal .Audience } \\
\text { interaction can be through } \\
\text { occasional email or in } \\
\text { person queries }\end{array}$ \\
\hline Assessment & $\begin{array}{l}\text { Formative and } \\
\text { summative } \\
\text { assessments }\end{array}$ & $\begin{array}{l}\text { Formative and } \\
\text { summative assessments }\end{array}$ & $\begin{array}{l}\text { Formative and summative } \\
\text { assessments }\end{array}$ & $\begin{array}{l}\text { Formative and summative } \\
\text { assessments }\end{array}$ \\
\hline
\end{tabular}

\section{CONCLUSION}

The proposal focuses on development of research skills progressively through engaging students in some form of 'inquiry' or 'research' during the four year of undergraduate management studies. The study considers the potential opportunities and strategies to support student engagement in research by building inquiry led learning environment. Advocating an inquiry approach can stimulate and motivate learners by setting off their curiosity this will as well assist them to gain relevant competencies required to work optimally as managers in Saudi Arabia.

\section{REFERENCES}

1. Healey, M. (2005). Linking research and teaching exploring disciplinary spaces and the role of inquiry-based learning. In: Barnett, R. (Ed.) Reshaping the university: new relationships between research, scholarship and teaching. Maidenhead: McGraw-Hill/Open University Press, 30-42.

2. Healey, M., Jenkins, A., \& Lea, J. (2014). Developing Research-Based Curricula in CollegeBased Higher Education. York: The Higher Education Academy.
3. Turner, N., Wuetherick, B., \& Healey, M. (2008) International perspectives on student awareness, experiences and perceptions of research: Implications for academic developers in implementing research-based teaching and learning. International Journal for Academic Development, 13(3):161-173.

4. Kuh, G. D., \& O'Donnell, K. (2013). Ensuring Quality and Taking High-Impact Practices to Scale. Washington, DC: American Association of Colleges and Universities.

5. Rowley, J., \& Slack, F. (2004) what is the future for undergraduate dissertations? Education and Training, 46(4):176-181

6. Brew, A. (2003). Teaching and research: new relationships and their implications for inquirybased teaching and learning in higher education, Higher Education Research \& Development 22(1):3-18.

7. Griffiths, R. (2004). Knowledge production and the research-teaching nexus: the case of the built environment disciplines. Studies in Higher Education, 29:709-726.

8. Healey, M., \& Jenkins, A. (2009). Developing undergraduate research and inquiry. York: Higher Education Academy. 
9. Levy, P., \& Petrulis, R. (2012). How do first-year university students experience inquiry and research, and what are the implications for the practice of inquiry-based learning? Studies in Higher Education, 37(1):85-101.

10. Elsen, M., Visser-Wijnveen, G. J., Van der Rijst, R. M., \& Van Driel, J. H. (2009). How to strengthen the connection between research and teaching in undergraduate university education. Higher Education Quarterly, 63(1), 6485 .

11. Willison, J., \& O’Regan, K. (2007). Commonly known, commonly not known, totally unknown: A framework for students becoming researchers. Higher Education Research and Development, 26(4):393-409.

12. Jenkins, M., \& Healey, M. (2012). Developing and embedding inquiry-guided learning across an institution. New Directions for Teaching and Learning, 2012(129), 27-37.

13. Braun, N. M. (2004). Critical thinking in the business curriculum. Journal of Education for Business, 79(4):232-236.

14. Brew, A. (2006). Research and Teaching: Beyond the divide. London: Palgrave Macmillan.

15. Cassidy, T. J. (2003). Education in the Arab states: preparing to compete in the global economy. In: Schwab, Klaus, Cornelius, Peter (Eds.), The Arab
World Competitiveness Report, World Economic Forum, Geneva, 218-234.

16. Yousif, M. A., Eldalo, A. S., Abd Allah, M. A., Al-Sawat, M. A., Al-Wahaibi, H. M., Al-Osaimi A. A., \& Al-Gethami, S. H. (2014). Pharmacy education instruction: preference and practices, Saudi students' perception. Saudi Pharmaceutical Journal, 22(4), 309-314.

17. AlWazaify, M., Matowe, L., Albsoul-Younes, A., \& Al-Omran, O. A. (2006), "Pharmacy education in Jordan, Saudi Arabia and Kuwait". American Journal of Pharmaceutical Education. 70(1).

18. Kolb, D. A. (1981). Learning styles and disciplinary differences. In A. W. Chickering and Associates (EDs.) The Modern American College. San Francisco: Jossey-Bass.

19. Kolb, D. A. (1984). Experiential Learning: Experience as the Source of Learning and Development. Englewood Cliffs, New Jersey: Prentice-Hall.

20. Spronken-Smith, R. A., Walker, R., Dickinson, K. J. M., Closs, G. P., Lord, J. M., \& Harland, T. (2011). Redesigning a curriculum for inquiry: An ecology case study. Instructional Science, 39(5):721-735.

21. George, D., \& Mallery, P. (2003). SPSS for Windows step by step: A simple guide and reference 11.0 update (4th ed.). Boston: Allyn \& Bacon. 